\title{
Resource partitioning between Microlophus occipitalis and Stenocercus puyango (Sauria: Tropiduridae) in Cerros de Amotape National Park, Tumbes, Peru
}

\section{Repartición de recursos entre Microlophus occipitalis y Stenocercus puyango (Sauria: Tropiduridae) en el Parque Nacional Cerros de Amotape, Tumbes, Perú}

\author{
Alfredo Guzmán* 1 \\ https://orcid.org/0000-0003-2873-8026 \\ alfrguzman@gmail.com \\ Juan Carlos Jordán ${ }^{2}$ \\ https://orcid.org/0000-0002-1790-9689 \\ juan.jordan@gmail.com

\section{*Corresponding author} \\ 1 Departamento de Herpetología, Museo de Historia \\ Natural, Universidad Nacional Mayor de San Marcos, \\ Perú. Av. Arenales 1256, Jesús María 15072, Lima, \\ Perú \\ 2 Centro de Investigación en Biología Tropical y Con- \\ servación- CINBIOTYC. Piura, Perú.

\section{Citación} \\ Guzmán A, Jordán JC. 2021. Resource partitioning \\ between Microlophus occipitalis and Ste- \\ nocercus puyango (Sauria: Tropiduridae) in \\ Cerros de Amotape National Park, Tumbes, \\ Peru. Revista peruana de biología 28(3): \\ e21115 (Agosto 2021). doi: http://dx.doi. \\ org/10.15381/rpb.v28i3.21115
}

\section{Presentado: $\quad 02 / 09 / 2020$ \\ Aceptado: $\quad 27 / 07 / 2021$ \\ Publicado online: 30/08/2021}

Editor:

José Perez

\section{Abstract}

Activity, microhabitat use, and diet are patterns commonly used to define the saurian community structure, because of differential exploitation allowing coexistence at the same time and place. We analyze resource partitioning between two sympatric saurian species, Stenocercus puyango and Microlophus occipitalis, in the transitional area of the Pacific Tropical Forest and the Dry Forest inside Cerros de Amotape National Park (PNCA) in Tumbes, northwestern of Peru. Microlophus occipitalis and S. puyango both showed a unimodal activity pattern with higher activity around 13:00 $\mathrm{h}$, with a mean body temperature of $34.83^{\circ} \mathrm{C}$ and $32.17^{\circ} \mathrm{C}$ respectively, observing a significant relationship between body and environmental (air and substrate) temperatures. Rocks and tree trunks were the most frequent microhabitats used by $M$. occipitalis while $S$. puyango were registered more frequently over leaf litter. The diets of both tropidurids were composed by arthropods, ants, and insect larvae mainly. Similarities in activity times (temporal niche) and diet (trophic niche) should be related to phylogenetic relationship and environmental characteristics of PNCA (seasonality, vegetal composition) meanwhile differences in space use and microhabitat thermal quality will be related to thermal quality in the area.

\section{Resumen}

Los horarios de actividad, el uso de microhábitat y dieta, son patrones comúnmente utilizados para dilucidar la estructura de una comunidad de saurios, ya que estos hacen un uso diferenciado de los recursos que explotan, lo que les permite coexistir de forma adecuada en el mismo tiempo y lugar. Analizamos la repartición de recursos entre dos especies simpátridas de saurios, Stenocercus puyango y Microlophus occipitalis, en la zona transicional entre el Bosque Tropical del Pacifico y el Bosque Seco en el Parque Nacional Cerros de Amotape (PNCA), departamento de Tumbes, analizando el solapamiento del nicho espacial, temporal y trófico entre ambas especies, incluyendo algunos aspectos de sus ecologías termales. Microlophus occipitalis y $S$. puyango presentaron un patrón de actividad unimodal con un pico de actividad hacia las 13:00 horas y una temperatura corporal promedio de 34.83 ${ }^{\circ} \mathrm{C}$ y $32.17^{\circ} \mathrm{C}$, respectivamente, registrándose una relación significativa entre la temperatura corporal y las temperaturas ambientales (aire y suelo). Los microhábitats más utilizados por $M$. occipitalis fueron los troncos caídos y rocas, mientras que $S$. puyango fue registrado principalmente sobre hojarasca. La dieta de ambos tropidúridos estuvo compuesta por artrópodos, principalmente hormigas y larvas de insectos. Las similitudes encontradas tanto en los horarios de actividad (nicho temporal) como en la dieta (nicho trófico), estarían asociadas a su parentesco filogenético y a características ambientales propias dentro del PNCA (estacionalidad, composición vegetal), mientras que las diferencias en el uso del espacio y temperaturas corporales entre ambas especies estarían relacionada a la calidad térmica de los microhábitats presentes en el área.

Keywords:

Ecology; lizards; dry forests; ecological niche; Peru.

Palabras clave:

Ecología; lagartijas; bosques secos; nicho ecológico; Perú. 


\section{Introduction}

Species coexistence inside a community has been attributed to ecological factors (competition and predation; Schoener 1974, 1975); however other explanations are suggested: morphological differences and physiology (Chase et al. 2002), foraging mode (Huey 1979), reproduction patterns (Colli et al. 1997), allopatric characteristics (Huey \& Pianka 1977, Huey 1979), among others. Based on its historic context (phylogeny), these species should present differences due to their evolutionary history rather than competitive pressures (Huey 1979, Vitt et al. 1999, Losos 2000, Pérez 2005). Otherwise, recent studies demonstrated that differential partitioning of biotic and abiotic resources is the principal factor for community structure (Mesquita \& Colli 2003, Mesquita et al. 2006), overall, on areas where resources are scarce (Pérez 2005, Jordán 2010).

Usually, species partitioned their resources over three dimensions of the ecological niche: temporal, spatial and trophic niche. So, species differs in their activity patterns, spaces where they exploit resources and prey consumption allowing the coexistence of several species on a community (Hutchinson 1957, MacArthur 1972, Pianka 1973, Dunham 1980, 1983, Vitt et al. 1999, Vanhooydonck et al. 2000).

Lizard species are "ideal models" for ecological research because they display several characteristics (i.e. thermoregulation, high site fidelity, low dispersal rate, territorial behavior) that had been well studied (Cowles \& Bogert 1944, Pianka 1973, Huey \& Pianka 1981, Huey et al. 1983, Vitt \& Pianka 1994, Vitt et al. 1999, 2003). Lizard resource use patterns have been studied widely in Australian desertic ecosystems (Pianka 1973, Huey \& Pianka 1977, Pianka 1986, Vitt 1991) while research on interactions inside lizard community structures had been increasing on Neotropical ecosystems (Colli et al. 1992, Vitt\& Colli 1994, Vitt \& Zani 1998, Vitt et al. 1999, Mesquita \& Colli 2003, Mesquita et al. 2006, Rocha et al. 2009) specially on Teiids and Tropidurids in Central and South America (Rocha \& Bergallo 1990, Vitt \& Colli 1994, Vitt \& Zani 1998, Faria \& Araujo 2004, Rocha et al. 2009, Ribeiro 2010).

The tropidurids lizards Microlophus occipitalis (Peters 1871) and Stenocercus puyango (Torres-Carvajal 2005) are distributed on northwestern Peru and southwestern Ecuador, using a broad variety of habitats as rocky boulders, bushes, and algarrobo trees (Prosopis sp.) (Dixon \& Wright 1975, Torres-Carvajal 2005). Regardless of their broad distribution range (Carrillo \& Icochea 1995, Torres-Carvajal 2005, 2007), few studies consider ecological traits for both species (Watkins 1996, 1997, 1998, Jordán \& Pérez 2012) which occupy in syntopy a narrow area inside Cerros de Amotape National Park.

Cerros de Amotape National Park holds the most important ecoregions of northwestern Peru: Equatorial Dry Forest and Pacific Tropical Forest (Brack-Egg 1986), showing a high endemism rate and connectivity for wildlife between both ecosystems (SERNANP 2012), and had been considering a "biodiversity hotspots" ("TumbesChocó-Magdalena”; Mittermeier et al. 2005). Regardless of these characteristics, few herpetological studies had been done inside this protected area (Tello 1998, Jordán 2006, 2010, 2011a, 2011b, Jordán \& Pérez 2012). The goal of this study is to analyze differences or similarities at the temporal, spatial, trophic niche, and thermal characteristics between Stenocercus puyango and Microlophus occipitalis which allows them to coexist in syntopy in Cerros de Amotape National Park.

\section{Material and methods}

Study area.- Data collection was done between El Caucho and La Angostura localities (Fig. 1) in the transitional area of the Pacific Tropical Forest and the Dry Forest inside Cerros de Amotape National Park (PNCA) in the northwestern region of Tumbes (SERNANP 2012) between August and September of 2012. The climate is relatively mild with an average annual temperature of $26{ }^{\circ} \mathrm{C}$ showing a highly marked seasonality with a dry season ranging from May to November and a wet season ranging from December to April with an annual average precipitation of $1450 \mathrm{~mm}$ (Ponte 1998).

Data Collection.- Data were collected by three herpetologists (360 man-hours) during 20 days at the dry season through visual encounter surveys (VES) (Crump $\&$ Scott 1994) with 30 minutes duration between 08:00 and 18:00 hours.

Activity pattern and thermal ecology:- For each observed individual, sighting hour was recorded and a histogram was elaborated from this data. A KolmogorovSmirnov test was used to determine possible differences in activity patterns for each species. Body, air, and substrate temperatures $\left({ }^{\circ} \mathrm{C}\right)$ were registered for each captured individual after Vitt \& Carvalho (1995). Temperatures were recorded with a cloacal thermometer Miller and Weber® to the nearest $0.2^{\circ} \mathrm{C}$. The relationship between body and environmental temperatures were analyzed by simple and multiple regressions as well as differences in temperatures for age, sex, and species with a variance analysis (ANOVA). The exposure degree to the sun (exposed: totally exposed to sunlight; filtered: exposed to scattered sunlight; shaded: under total vegetation cover) for each observed individual were registered and analyzed with an ANOVA with exposure degree as factors (Vitt et al. 1995).

Microhabitat Use.- Eight microhabitats categories were identified in the study site for the study species: (1) leaf litter (substrate covered by leaf litter totally), (2) soil (substrate without leaf litter), (3) gravel $(<5 \mathrm{~cm})$, (4) sand, (5) tree branches, (6) trunks, (7) vegetation (crawling, herbs, shrubs), and (8) stones ( $>5 \mathrm{~cm}$ ). Potential differences in microhabitat use between age, sex, and species were assessed with a Chi-square test.

Diet.- All captured lizards were sacrificed immediately with Halatal $®$ and preserved on $70^{\circ}$ alcohol. Stomachs were dissected and analyzed under a stereomicroscope identifying prey items to order level (including broad categories as insect larvae). A Kolmogorov-Smirnov test was used to determine differences in diet composition consumed by lizard species. 


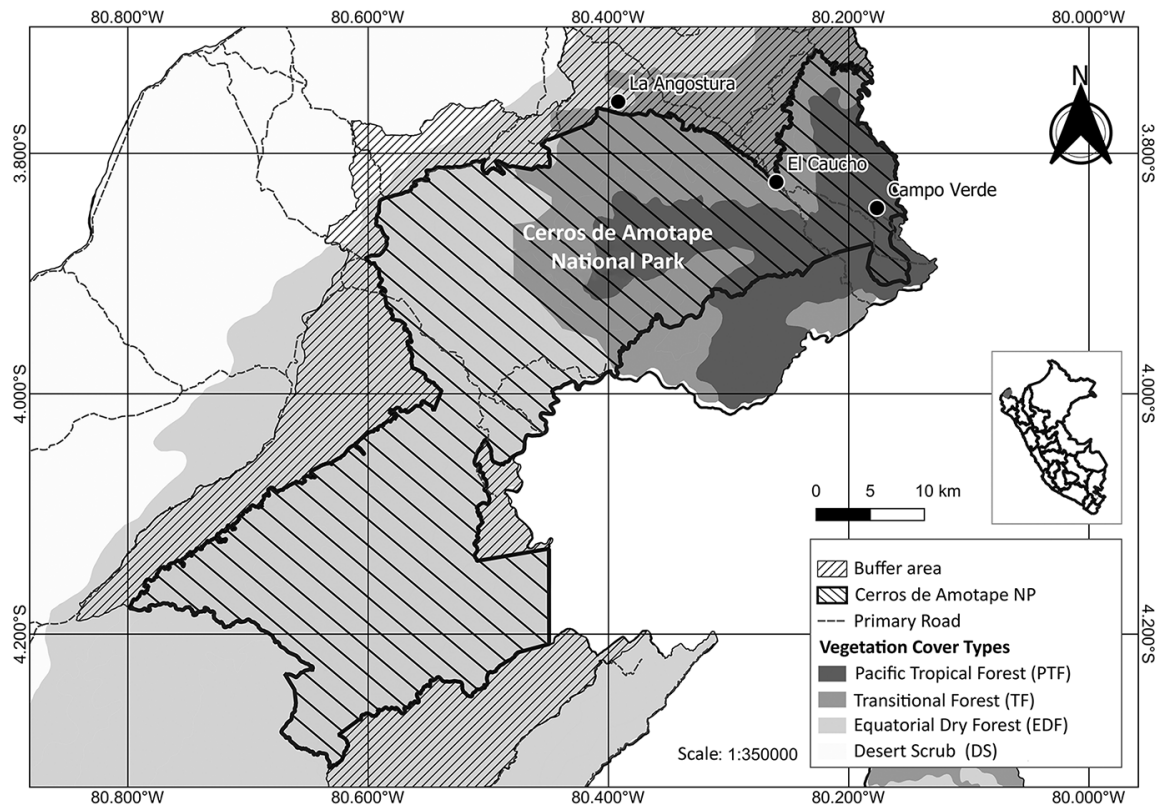

Figure 1. Study area located between La Angostura and El Caucho localities inside Cerros de Amotape National Park.

Niche breadth.- We compute niche breadth (spatial, temporal, and trophic) using the inverse of Simpson's diversity index formula of Simpson (Simpson 1949, Pianka 1973, Vitt \& Zani 1996:

$$
B=\frac{1}{\sum_{i}^{n} p^{2}}
$$

Niche breadth value range from 1 to $n$, where low values indicate a restricted use of resources while high values indicate an intensive use (Vitt \& Zani 1996). The overlapping degree of the spatial, temporal and trophic niche was evaluated with the symmetric overlap index $\left(\Phi_{\mathrm{j} k}\right)$ where values near to 0 indicate a low overlap while values near or equal to 1 indicate a high overlap on the resource used (Pianka 1973, 1986):

$$
\emptyset_{j k}=\frac{\sum_{n=1} p_{i j} p_{i k}}{\sqrt{\sum_{i=1}^{n} p_{i j}^{2} \sum_{i=1}^{n} p_{i k}^{2}}}
$$

We generated 1000 repetitions using EcoSim 700 software (Gotelli \& Entsminger 2004) and comparing "real" data matrix (observed) with "simulated" matrix (simulated) through a Monte Carlo analysis using R3 algorithm (Pianka 1973, 1986) to determine if overlap on any niche dimension (trophic, spatial, temporal) is a real structure or a random result (Winemiller \& Pianka 1990, Gotelli \& Entsminger 2004, Rouag et al. 2007). The recommended R3 algorithm retains niche breadth (or specialization degree) of each species in the simulated matrices but "allow" the potential use of other unexploited resources (Winemiller \& Pianka 1990, Gotelli \& Entsminger 2004, Rouag et al. 2007).

Statistical analysis.- We used PAST $₫$ Version 3.0 (Hammer et al. 2001) with a significance level $(\alpha) \leq 0.05$ for statistical analysis. Normality was verified through an Anderson-Darling test before parametric or non-parametric statistics were applied; variance homogeneity was analyzed with the Levene test. Data means appear $\pm 1 \mathrm{SD}$ in text. All collected individuals were deposited on the Department of Herpetology, Natural History Museum, Universidad Nacional Mayor de San Marcos.

\section{Results}

Activity pattern.- A total of 408 sightings of both species Stenocercus puyango and Microlophus occipitalis (Fig. 2) were registered between 8:00 and 16:00 hours (216 and 192 respectively).

A higher proportion of Stenocercus puyango sightings (52.9\%) were registered between 10:00 and 15:00 hours while $47.1 \%$ of Microlophus occipitalis sightings were registered between 10:00 and 13:00 hours (Fig. 3). No significant differences between activity patterns for both species were registered $\left(D_{\max }=0.18, p>0.05\right)$, indicating both species exhibit a unimodal activity pattern.

Thermal ecology.- Average body temperature of Microlophus occipitalis was higher than Stenocercus puyango average body temperature as well as the related environmental (air and substrate) temperatures (Table 1). Body temperatures of each species differ significantly $\left(F_{(1,113)}=35.84 ; \mathrm{p}<0.05\right)$, indeed air $\left(\mathrm{F}_{(1,113)}=5.28 ; \mathrm{p}<0.05\right)$ and substrate temperatures $\left(\mathrm{F}_{(1,113)}=10.32 ; \mathrm{p}<0.05\right)$.

Body temperature of Stenocercus puyango was significantly related with air temperature $\left(T_{a}\right)\left(R^{2}=0.53\right.$, $\left.\mathrm{F}_{(1,57)}=66.88, \mathrm{p}<0.05, \mathrm{n}=58\right)$ and substrate $\left(\mathrm{T}_{\mathrm{s}}\right)\left(\mathrm{R}^{2}=0.42\right.$, $\mathrm{F}_{(1,57)}=40.83, \mathrm{p}<0.05, \mathrm{n}=58$ ) (Figure 4 and 5). Also, body temperature of $M$. occipitalis was significantly related with air temperature $\left(R^{2}=0.22, F_{(1.55)}=15.57, p<0.05\right.$; $\mathrm{n}=56)$ and substrate $\left(\mathrm{R}^{2}=0.24, \mathrm{~F}_{(1,55)}=17.9, \mathrm{p}<0.05 ; \mathrm{n}=57\right)$ (Figs. 4 and 5). 
Table 1. Body temperature ( $\mathrm{Tb}$ ), air temperature ( $\mathrm{Ta}$ ) and substrate temperature (Ts) recorded for both species in Cerros de Amotape National Park. Mean \pm standard deviation and range are showed.

\begin{tabular}{lcccccc}
\hline Species & $\mathrm{T}_{\mathrm{b}}\left({ }^{\circ} \mathrm{C}\right)$ & $\begin{array}{c}\text { Range } \\
(\mathbf{m a x}-\mathbf{m i n})\end{array}$ & $\mathrm{T}_{\mathrm{a}}\left({ }^{\circ} \mathrm{C}\right)$ & $\begin{array}{c}\text { Range } \\
(\mathbf{m a x}-\mathbf{m i n})\end{array}$ & $\mathbf{T}_{\mathrm{s}}{ }^{\left({ }^{\circ} \mathbf{C}\right)}$ & $\begin{array}{c}\text { Range } \\
(\mathbf{m a x}-\mathbf{m i n})\end{array}$ \\
\hline Stenocercus puyango & $32.0 \pm 2.65$ & $24.8-37$ & $28.6 \pm 3.34$ & $22.4-37.6$ & $28.9 \pm 3.76$ & $22.4-39.2$ \\
Microlophus occipitalis & $34.8 \pm 2.23$ & $27.4-38.2$ & $30.1 \pm 3.27$ & $23.2-38.6$ & $31.4 \pm 3.84$ & $24.0-43.0$ \\
\hline
\end{tabular}

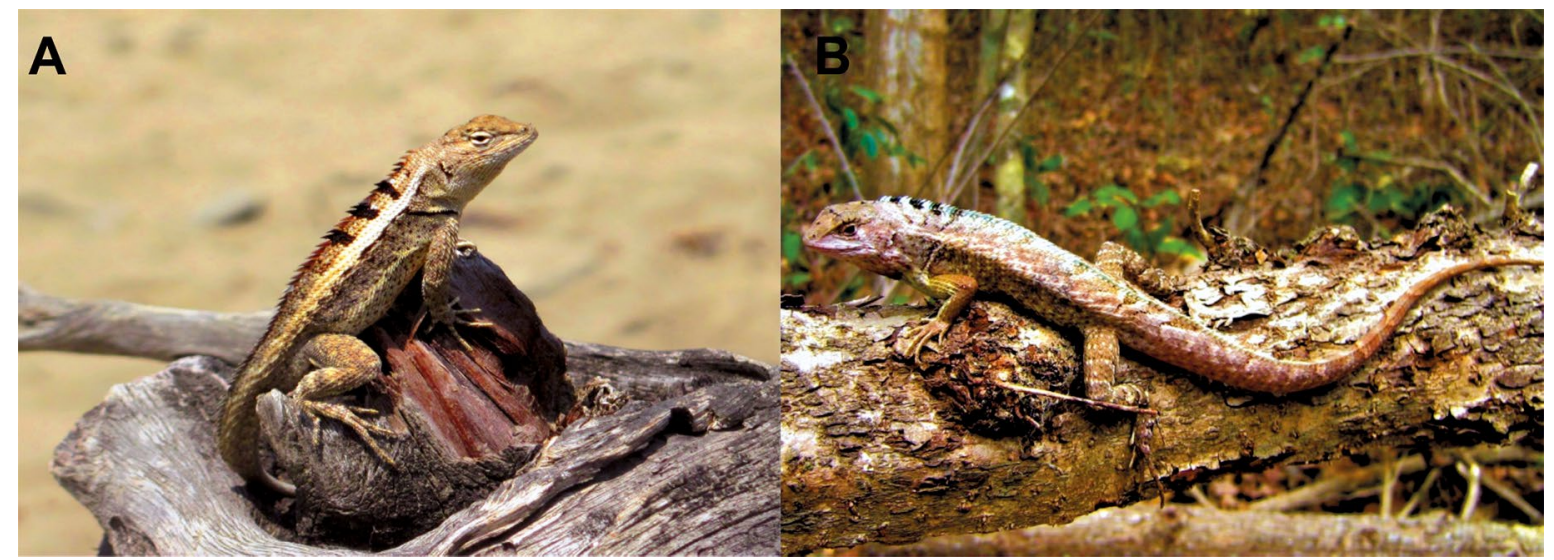

Figure 2. (a) Microlophus occipitalis (adult male) and (b) Stenocercus puyango (adult male) in Cerros de Amotape National Park.

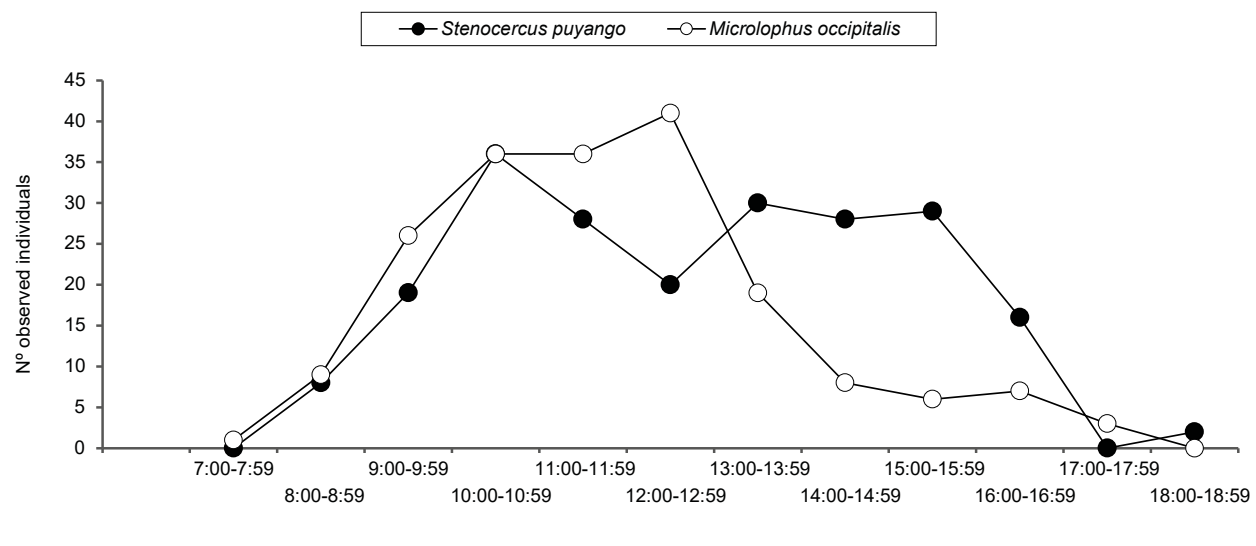

Figure 3. Activity pattern of Microlophus occipitalis and Stenocercus puyango in Cerros de Amotape National Park.

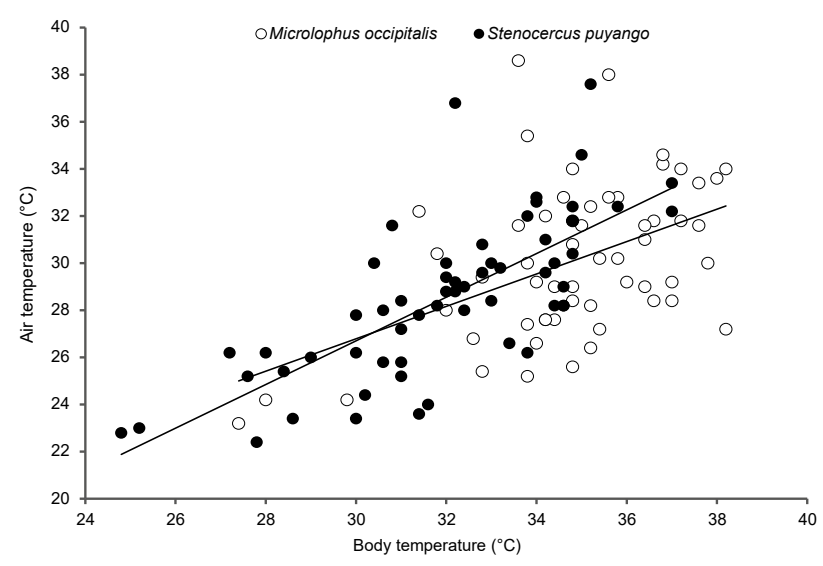

Figure 4. Relationship between body and air temperature of $\mathrm{Mi}$ crolophus occipitalis $\left.\left(R^{2}=0.22, F_{(1.55}\right)=15.57, p<0.05 ; n=56\right)$ and Stenocercus puyango $\left(R^{2}=0.53, F_{(1,57)}=66.88, p<0.05, n=58\right)$.

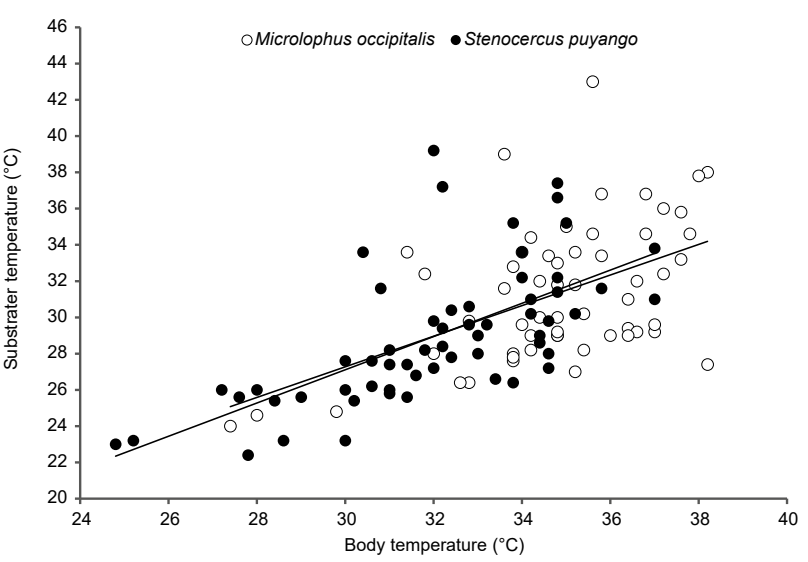

Figure 5. Relationship between body and substrate temperature of Microlophus occipitalis $\left(R^{2}=0.24, F_{(1.55)}=17.9, p<0.05 ; n=57\right)$ and Stenocercus puyango $\left(R^{2}=0.42, F_{(1,57)=} 40.83, p<0.05, n=58\right)$. 
Multiple regression showed that environmental temperatures $\left(\mathrm{T}_{\mathrm{a}}\right.$ and $\mathrm{T}_{\mathrm{s}}$ ) influenced significantly over body temperature of Stenocercus puyango $\left(\mathrm{R}^{2}=0.52\right.$; $\left.\mathrm{F}_{(2.53)}=29.55 ; \mathrm{p}<0.05 ; \mathrm{n}=58\right)$ and $M$. occipitalis $\left(\mathrm{R}^{2}=0.23\right.$; $\left.\mathrm{F}_{(2,54)}=8.96 ; \mathrm{p}<0.05 ; \mathrm{n}=57\right)$.

A higher proportion of Stenocercus puyango was registered under filtered sun $(n=148,68 \%)$ follow by individuals exposed to sun $(n=45,21 \%)$ and shade $(n=23$, $11 \%)$, while $M$. occipitalis was recorded exposed to sun $(\mathrm{n}=113,59 \%)$, and a lower proportion under filtered sun $(n=66,34 \%)$ and shade (n=13, 7\%) (Fig. 6).

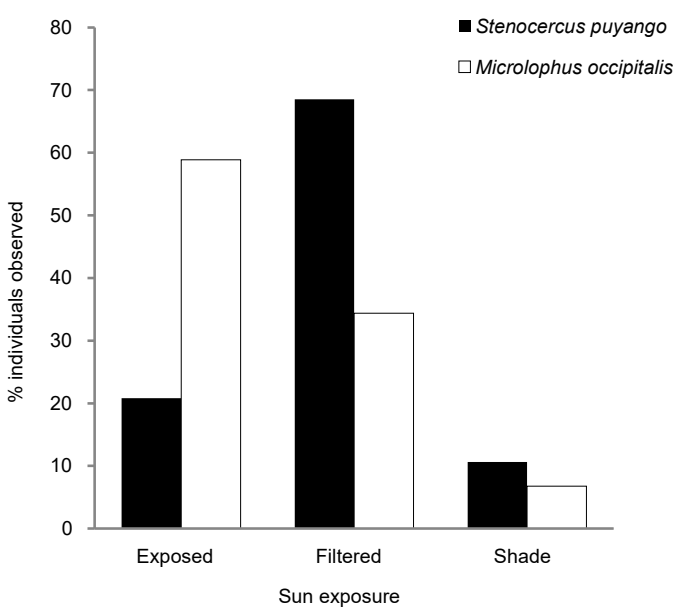

Figure 6. Exposure degree to sun of Microlophus occipitalis and Stenocercus puyango in Cerros de Amotape National Park.

Microhabitat use.- Leaf litter was the most used microhabitat by $S$. puyango $(n=216) \quad(50.9 \%$ of all records) followed by trunks and stones $(16.2 \%$ and
$15.3 \%$, respectively; Fig. 7). Individuals of $M$. occipitalis $(\mathrm{n}=192)$ were registered on trunks $(34.9 \%)$, stones and grave (28.13\% and $14.06 \%$, respectively). Significant differences were found in microhabitat use among the eight identified categories by $S$. puyango and $M$. occipitalis $\left(\chi^{2}=155.78, \mathrm{p}<0.05\right)$. Spatial niche breadth (Bs) for S. puyango and $M$. occipitalis were 2.49 y 3.39 respectively.

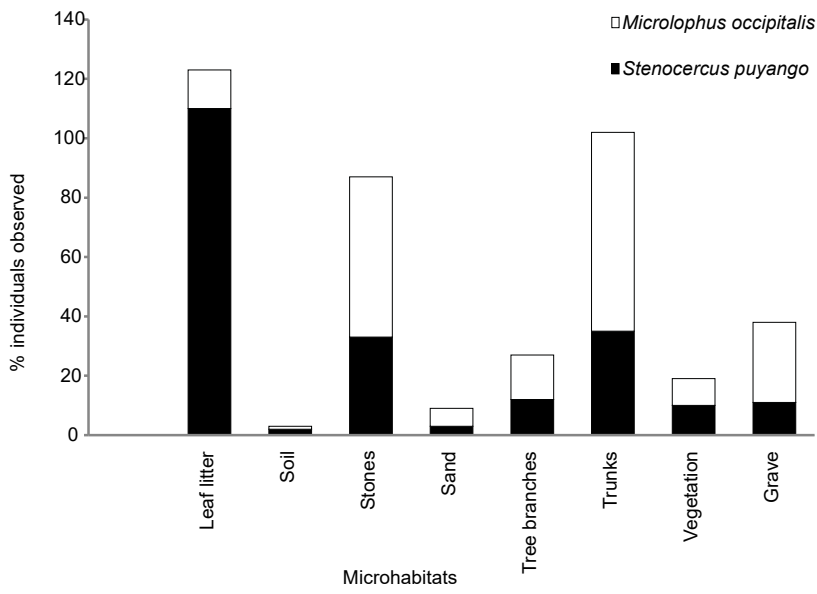

Figure 7. Microhabitat use of Microlophus occipitalis and Stenocercus puyango in Cerros de Amotape National Park.

Diet.- Diet of $S$. puyango $(\mathrm{n}=55)$ and M. occipitalis $(\mathrm{n}=60)$ was composed of 17 and 15 different types of prey items, respectively (Table 2), where hymenopterans and insect larvae were the most consumed prey items by both species.

Table 2. Diet composition of Microlophus occipitalis $(\mathrm{N}=55)$ and Stenocercus puyango $(\mathrm{N}=60)$ in Cerros de Amotape National Park. $\mathrm{N}$-number of prey items; \%N-percentage of prey items consumed, F- frequency of prey items in stomachs, \%F- percentage of prey items frequency.

\begin{tabular}{|c|c|c|c|c|c|c|c|c|}
\hline \multirow{2}{*}{ Prey items } & \multicolumn{4}{|c|}{ Stenocercus puyango $(n=55)$} & \multicolumn{4}{|c|}{ Microlophus occipitalis $(\mathrm{n}=60)$} \\
\hline & $\mathbf{N}$ & $\mathbf{N} \%$ & $\mathbf{F}$ & $\mathbf{F} \%$ & $\mathbf{N}$ & N\% & $\mathbf{F}$ & $\mathbf{F} \%$ \\
\hline Hymenoptera (Formicidae) & 80 & 26.58 & 0.183 & 18.274 & 87 & 33.33 & 0.229 & 22.9 \\
\hline Larvas de insectos & 64 & 21.26 & 0.162 & 16.244 & 79 & 30.27 & 0.200 & 20.0 \\
\hline Orthoptera & 39 & 12.96 & 0.152 & 15.228 & 24 & 9.2 & 0.193 & 19.3 \\
\hline Coleoptera & 32 & 10.63 & 0.142 & 14.213 & 33 & 12.64 & 0.129 & 12.9 \\
\hline Hemiptera & 26 & 8.64 & 0.102 & 10.152 & 10 & 3.83 & 0.071 & 7.1 \\
\hline Aranae & 22 & 7.31 & 0.096 & 9.645 & 4 & 1.53 & 0.029 & 2.9 \\
\hline Diptera & 12 & 3.99 & 0.056 & 5.584 & 4 & 1.53 & 0.029 & 2.9 \\
\hline Lepidoptera & 9 & 2.99 & 0.041 & 4.061 & 2 & 0.78 & 0.029 & 2.9 \\
\hline Restos vegetales & 5 & 1.66 & 0.010 & 1.015 & 1 & 0.38 & 0.014 & 1.4 \\
\hline Isoptera & 4 & 1.33 & 0.015 & 1.523 & 1 & 0.38 & 0.014 & 1.4 \\
\hline Phasmatodea & 2 & 0.66 & 0.010 & 1.015 & 3 & 1.15 & 0.014 & 1.4 \\
\hline Blattodea & 2 & 0.66 & 0.010 & 1.015 & 5 & 1.92 & 0.014 & 1.4 \\
\hline Odonata & 2 & 0.66 & 0.010 & 1.015 & 1 & 0.38 & 0.007 & 0.7 \\
\hline Nematoda (silvestre) & 1 & 0.33 & 0.005 & 0.508 & 2 & 0.78 & 0.007 & 0.7 \\
\hline Decapoda (exoesqueleto) & 1 & 0.33 & 0.005 & 0.508 & 2 & 0.78 & 0.007 & 0.7 \\
\hline Mantodea & - & - & - & - & 2 & 0.78 & 0.007 & 0.7 \\
\hline Escorpioidea & - & - & - & - & 1 & 0.38 & 0.007 & 0.7 \\
\hline
\end{tabular}


Stenocercus puyango consumed hymenopterans $(26.58 \%)$, orthopterans $(12.96 \%)$, coleopterans (10.63\%), and hemipterans (8.64\%), and a higher percentage of insect larvae (21.26\%) both in frequency and numerically. Predominant preys in $M$. occipitalis diet were hymenopterans (33.33\%), coleopterans (12.64\%), orthopterans $(9.2 \%)$, and elevated consumption of insect larvae $(30.27 \%)$ with similar results in frequency (Table 1). Significant differences in numerical diet composition between both species were not found $\left(D_{\max }=0.18, p>0.05\right)$.

Niche breath and niche and overlap.- Stenocercus puyango showed a wider temporal niche breadth $\left(\mathrm{B}_{\mathrm{t}}\right)$ than M. occipitalis $\left(\mathrm{B}_{\mathrm{ts}}=8.28\right.$ and $\mathrm{B}_{\mathrm{tm}}=6.65$, respectively) and the temporal niche overlap $\left(\Phi_{\mathrm{j} j}\right)$ between both tropidurids was higher $\left(\Phi_{\mathrm{jk}}=0.84\right.$; p obs $\left.\geq \mathrm{esp}=0.01\right)$ (Table 2). Spatial niche breadth $\left(\mathrm{B}_{\mathrm{s}}\right)$ was wider for M. occipitalis $\left(\mathrm{B}_{\mathrm{sm}}=4.26\right)$ than $S$. puyango $\left(\mathrm{B}_{\mathrm{ss}}=3.15\right)$, however, both species showed a lower overlap on this niche axis $\left(\Phi_{\mathrm{jk}}=0.54\right.$; $\mathrm{p}$ obs $\geq \mathrm{esp}=$ 0.001) (Table 3). Otherwise, trophic niche breadth was wider for Stenocercus puyango than for M. occipitalis $\left(\mathrm{B}_{\mathrm{ds}}=6.26\right.$ and $\mathrm{B}_{\mathrm{dm}}=4.35$, respectively), with a higher trophic niche overlap $\left(\Phi_{\mathrm{jk}}=0.96\right.$; p obs $\left.\geq \operatorname{esp}=0.001\right)$.

Table 3. Niche breadth and niche overlap between Microlophus occipitalis and Stenocercus puyango. Bt: temporal niche breadth. Bs: Spatial niche breadth. Bd: trophic niche breadth.

\begin{tabular}{lccc} 
& $\mathbf{B}_{\mathbf{t}}$ & $\mathbf{B}_{\mathbf{s}}$ & $\mathbf{B}_{\mathbf{d}}$ \\
\hline Microlophus occipitalis & 6.65 & 4.26 & 4.35 \\
Stenocercus puyango & 8.28 & 3.15 & 6.26 \\
$\Phi_{\mathrm{jk}}$ & 0.84 & 0.54 & 0.96 \\
\hline
\end{tabular}

The values of the null modes ( $\mathrm{p}$ observed $\geq$ simulated) were lower than the significance level established ( $p>0.05$ ) indicating the existence of a real structure for each ecological niche dimension for these lizard species.

\section{DISCUSSION}

Microlophus occipitalis and Stenocercus puyango showed a higher overlap on the temporal and trophic niche and lower overlap in spatial niche; in other words, they are active at the same hours and feeding on similar prey items, while the greater difference was observed on the spatial niche.

Ecological similarities such as their heliophilic and diurnal habits of both species may be related to their evolutionary similarity since both belongs to Tropiduridae lizard family (Bergallo \& Rocha 1993, Rocha et al. 2009) and reflecting the wide temporal niche breadth of both species, as well as their high temporal overlap. Diurnal activity patterns attributed to sunny hours for both species could be related to their thermal demands (Hatano et al. 2001), allowing them to develop their ecological activities (Bauwens et al. 1996, Smith \& Ballinger 2001). This same diurnal activity pattern with a midday activity peak had been reported for other tropidurid species in the Peruvian coastal desert (M. peruvianus- Huey
1974, Catenazzi et al. 2005, Pérez \& Balta 2007, M. tigrisPérez 2005, Jordán 2011, M. theresiae and M. thoracicusPérez \& Balta 2007).

A similar activity pattern, reflected by a high temporal niche overlap, may be an important factor for similar diet composition for both sympatric species because they could be exposed to the same preys set, explaining the high trophic niche overlap. This similarity on prey consumption could be related to seasonality (dry season in this case) due to reduced prey abundance and diversity related to limited availability of resources (vegetation) pushing lizards to prey over a similar and limited set of arthropods and other items. Ribeiro \& Freire (2011) reported a similar case where a high trophic niche overlap was registered during the dry season between two tropidurid species (Tropidurus hispidus and T. semitaeniatus) in northeastern Brazil.

Foraging mode could influence diet similarity for both species. Lizards exhibiting an ambush foraging strategy eats mobile preys while active foraging lizards eats sedentary preys (Huey \& Pianka 1981). Microlophus occipitalis and $S$. puyango showed an arthropodbased diet, a basal condition for Neotropical lizards (Vitt et al. 2003), where ants (Formicidae) and insect larvae were the more abundant and frequent consumed preys. The high mobile preys consumption should be related to their foraging mode (sit and wait foragers, Schoener 1971) however a significative proportion of insect larvae, a low/mobility preys, were found on stomachs. This result reflects an intermediate foraging mode dependent of prey item availability in their environment as had been pointed by Huey \& Pianka (1981) for lizards and reported by other authors in tropidurines (Bergallo \& Rocha 1993, Pérez 2005). A similar pattern was found by Ribeiro \& Freire (2011) for Tropidurus hispidus and T. semitaeniatus diet in northeastern Brazil and Meira et al. (2007) in central Brazil for $T$. oreadicus, were a mixed diet composed by active (Formicidae and Orthoptera) and lumped or sedentary items (termites and insect larvae) were registered. This plasticity in foraging mode probably allows Stenocercus puyango and Microlophus occipitalis to eat a wide variety of prey items, saving time and energy intake while preying (Ribeiro 2010). Both species showed a wide trophic niche, like other peruvian tropidurid species, indeed occupying distinct habitats as beaches (Microlophus peruvianus, Quispitúpac \& Pérez 2008), lomas (or foothills, Microlophus tigris, Pérez 2005) and desert (Microlophus theresiae, Pérez \& Balta 2007). Thus, $S$. puyango and $M$. occipitalis could be considered as generalist predators. However, Chávez-Villavicencio et al. (2018) reported a narrow niche breadth for Microlophus occipitalis $\left(\mathrm{B}_{\mathrm{t}}=0.13\right)$ explained by a high consumption of ants, around $58.9 \%$ compared to the $26.6 \%$ of this study and a lower consumption of other items. This could be related to prey abundance and vegetation composition among sites where the study site of Chavez-Villavicencio et al (2018) considered as "algarrobal" shows a minor vegetation complexity than the tropical dry forest in Tumbes. 
Differences in microhabitat use could be related to specific thermal demands of each species, selecting microhabitats with favorable thermal characteristics. Both species in this study showed significant differences in body temperature, where $M$. occipitalis showed a higher body temperature (Jordán \& Pérez 2012), indicating greater thermal needings than $S$. puyango. Also, environmental (air and substrate) temperatures in $M$. occipitalis were significantly higher than values recorded for $S$. puyango, indicating a selection for microhabitats with higher temperatures. Additionaly, Microlophus occipitalis is small lizard with a higher superficial area-volume relationship compared to $S$. puyango, so is probably this species loss heat at a higher rate, selecting "warmer" areas for thermoregulation at wide time intervals to reach its optimal body temperature.

In this sense, M. occipitalis selects open and sunny patches as microhabitats in the forest for thermoregulation, maintaining higher and stable body temperatures (Jordán \& Pérez 2012). On the other hand, S. puyango inhabits inside the forest, selecting filtered-sun microhabitats including fallen tree trunks and leaf litter. Similar results were registered by Dias \& Rocha (2004) for two Cnemidophorus (Teiidae) species in northeastern Brazil where differences in microhabitat selection were related to exposure degree and vegetative cover. Thus, thermal environment influences body temperature in lizards (Smith \& Ballinger 2001), including complex relationships with physical variables (wind, air and substrate temperature, radiation, etc.) (Tracy 1982, Olivera 2015).

Niche overlap was higher in trophic and temporal axis but lower in microhabitat use relative to the other two axes explaining the coexistence of these two lizard species. Monte Carlo simulations for the three ecological niche axis indicated that overlapping patterns are real (due to phylogenetics- related similarities) rather than random.

In conclusion, differences in spatial use between $\mathrm{Mi}$ crolophus occipitalis and Stenocercus puyango would be related to differential resources use, allowing the coexistence of both species in sympatry inside of Cerros de Amotape National Park.

\section{Literature cited}

Bauwens D, Hertz PE, Castilla AM. 1996. Thermoregulation in a lacertid lizard: the relative contributions of distinct behavioral mechanisms. Ecology 77(6):1818-1830. https://doi.org/10.2307/2265786

Bergallo HG, Rocha CFD. 1993. Activity patterns and body temperatures of two sympatric lizards (Tropidurus torquatus and Cnemidophorus ocellifer) with different foraging tactics in southeastern Brazil. Amphibia-Reptilia 14(3):312-315. https://doi. org/10.1163/156853893X00525

Brack-Egg A. 1986. Las ecorregiones del Perú. Boletín de Lima 44:57-70.

Carrillo N, Icochea J. 1995. Lista Taxonómica Preliminar de los Reptiles Vivientes del Perú. Public. Mus Hist. Nat. (UNMSM) Serie A, Zoología, 49:1-27.
Catenazzi A, Carrillo J, Donnelly M. 2005. Seasonal and geographic eurythermy in a coastal Peruvian lizard. Copeia 2005(4) :713-723. https://www.jstor.org/stable/4098645

Chase JM, Abrams PA, Grover JP, Diehl S, Chesson P, Holt RD, Richards SA, Nisbet RM, Case TJ. 2002. The interaction between predation and competition: a review and synthesis. Ecology Letters 5:302-315. https://doi. org/10.1046/j.1461-0248.2002.00315.x

Chávez-Villavicencio C, Ibañes-Álvarez Y, Charcape-Ravelo JM. 2018. Selección de hábitat y composición de la dieta de Microlophus occipitalis (Reptilia: Tropiduridae) en Sechura. Piura-Perú. Revista Peruana de Biología 25(3):221-228. http://dx.doi.org/10.15381/rpb. v25i3.13403

Colli GR, Péres AK, Zatz MG. 1997. Foraging mode and reproductive seasonality in tropical lizards. Journal of Herpetology 31(4):490-499. https://doi. org/10.2307/1565600

Colli GR, Araújo AFB, Silveira R, Roma F. 1992. Niche partitioning and morphology of two syntopic Tropidurus (Sauria: Tropiduridae) in Mato Grosso, Brazil. Journal of Herpetology 26(1):66-69. https://doi. org/10.2307/1565023

Cowles RB, Bogert CM. 1944. A preliminary study of the thermal requirements of desert reptiles. Bulletin of the American Museum of Natural History 83:265-296. http://hdl.handle.net/2246/1237

Crump ML, Scott NJ. 1994. Visual encounter surveys. In: Heyer WR, Donnelly MA, McDiarmid RW, Hayek LC, Foster MS (Eds). Measuring and Monitoring Biological Diversity: Standard Methods for Amphibians. Smithsonian Institution: Washington DC. Pp. 84-92.

Dias EJR, Rocha CFD. 2004. Thermal ecology, activity patterns, and microhabitat use by two sympatric whiptail lizards (Cnemidophorus abaetensis and Cnemidophorus ocellifer) from northeastern Brazil. Journal of Herpetology 38(4):586-588. https://doi.org/10.1670/80-03N

Dunham AE. 1983. Realized niche overlap, resource abundance and intensity of interspecific competition. In: Huey RB, Pianka ER, Schoener TW (Eds). Lizard Ecology: Studies of Model Organism. Harvard University Press, Cambridge, Massachusetts, USA. Pp. 261-280. https:// doi.org/10.4159/harvard.9780674183384.c15

Dunham AE. 1980. An experimental study of interspecific competition between the iguanid lizards Sceloporus merriami and Urosaurus ornatus. Ecological Monographs 50(3):309-330. https://doi.org/10.2307/2937254

Faria RG, Araujo AFB. 2004. Sintopy of two Tropidurus lizard species (Squamata: Tropiduridae) in a rocky Cerrado habitat in Central Brazil. Brazilian Journal of Biology 64(4):775-786. https://doi.org/10.1590/S151969842004000500007

Gotelli NJ, Entsminger GL. 2004. EcoSim: Null models software for ecology. Version 7. Acquired Intelligence Inc. \& Kesey-Bear. Jericho, VT 05465. Computer software. http://garyentsminger.com/ecosim/index.htm

Hatano FH, Vrcibradic D, Galdino CAB, Cunha-Barros M, Rocha CFD, Van Sluys M. 2001. Thermal ecology and activity patterns of the lizard community of the Restinga of Jurubatiba, Macaé, RJ. Revista Brasileira de Biologia 61 (2):287-294. https://doi.org/10.1590/S003471082001000200011 
Hammer O, Harper DAT, Ryan PD. 2001. Past: Paleontologica Statistics Software Package for education and data analysis. Paleontologia Electronica 4:1-9. https:// palaeo-electronica.org/2001_1/past/issue1_01.htm

Huey RB. 1983. Temporal separation activity and interspecific dietary overlap. In: Huey RB, Pianka ER, Schoener TW (Eds). Lizard Ecology, Studies of a model organism. Harvard University Press, USA. Pp. 281-296.

Huey RB. 1982. Temperature, physiology, and the ecology of reptiles. In: Gans C, Pough FH (Eds). Biology of the Reptilia. Academic Press, London. Pp. 25-91.

Huey RB, Pianka ER. 1981. Ecological consequences of foraging mode. Ecology 62(4):991-999. https://doi. org $/ 10.2307 / 1936998$

Huey RB. 1979. Parapatry and niche complementarity of Peruvian desert geckos (Phyllodactylus): the ambiguous role of competition. Oecologia 38(3):249-259. https://doi.org/10.1007/BF00345186

Huey RB, Pianka ER. 1977. Patterns of niche overlap among broadly sympatric versus narrowly sympatric Kalahari lizards (Scincidae: Mabuya). Ecology 58:119-128. https://doi.org/10.2307/1935113

Hutchinson GE. 1957. Concluding Remarks. Cold Spring Harbor Symposia on Quantitative Biology 22:415-427. http:// dx.doi.org/10.1101/SQB.1957.022.01.039

Jordán JC, Pérez ZJ. 2012. Thermal ecology of Microlophus occipitalis (Sauria: Tropiduridae) in the Plain Dry Forest of Tumbes, Peru. Revista Peruana de Biología 19(1):9799. https://doi.org/10.15381/rpb.v19i1.794

Jordán JC. 2010. Repartición de recursos en dos especies simpátridas de Ameiva (Sauria: Teiidae) en el Parque Nacional Cerros de Amotapes, Tumbes, Perú. Tesis para optar al Título profesional de Biólogo, Facultad de Ciencias Biológicas, Universidad Nacional Mayor de San Marcos. https://hdl.handle. net/20.500.12672/16466

Jordán JC. 2006. Dieta de Phylodactylus reisi en la Zona Reservada de Tumbes, Perú. Revista Peruana de Biología 13(1):121-23. https://doi.org/10.15381/rpb. v13i1.1774

Jordán JC. 2011a. Notes on the ecology of Phyllodactylus reissi (Phyllodactylidae: Sauria) in Parque Nacional Cerros de Amotape (Tumbes, Peru). Revista Peruana de Biología 18(3):377-380. https://doi.org/10.15381/rpb. v18i3.456

Jordán JC. 2011b. Note on the diet of Ameiva edracantha (Squamata, Teiidae) in Cerros de Amotape National Park, Tumbes, Peru. Revista Peruana de Biología, 18(2):253255. https://doi.org/10.15381/rpb.v18i2.239

Losos JB. 2000. Ecological character displacement and the study of adaptation. Proceedings of the National Academy of Sciences 97(11):5693-5695. https://doi. org/10.1073/pnas.97.11.5693

MacArthur RH. 1972. Geographical ecology: patterns in the distribution of species. Princeton University Press, $288 \mathrm{pp}$.

Meira KTR, Faria RG, Silva MDM, Miranda VT, Zahn-Silva W. 2007. História natural de Tropidurus oreadicus em uma área de cerrado rupestre do Brasil Central. Biota Neotropica 7(2):155-164. https://doi.org/10.1590/ S1676-06032007000200018

Mesquita DO, Colli GR, França FGR, Vitt LJ. 2006. Ecology of a Cerrado Lizard Assemblage in the Jalapão region of Brazil. Copeia 2006(3):460-471. https://doi.org/10.1643/00458511(2006)2006[460:EOACLA]2.0.CO;2
Mesquita DO, Colli GR. 2003. The Ecology of Cnemidophorus ocellifer (Squamata, Teiidae) in a Neotropical Savanna. Journal of Herpetology 37(3):498-509. https:// www.jstor.org/stable/1566053

Mittermeier RA, Gill PR, Hoffmann M, Pilgrim J, Brooks J, Mittermeier CJ, Lamourux J, Fonseca GAB. 2005. Hotspots Revisited: Earth's Biologically Richest and Most Endangered terrestrial ecoregions, CEMEX, Washington, $392 \mathrm{pp}$.

Olivera DA. 2015. Ecología termal de Microlophus tigris (Tschudi, 1845) (Sauria: Tropiduridae) "Lagartija de las lomas" en dos altitudes en la región Lima (Perú) durante la época seca. Tesis para optar al Título profesional de Biólogo, Facultad de Ciencias Biológicas, Universidad Nacional Mayor de San Marcos. https:// hdl.handle.net/20.500.12672/4217

Pérez ZJ, Balta K. 2007. Ecología de la comunidad de saurios diurnos de la Reserva Nacional de Paracas, Ica, Perú. Revista Peruana de Biología 13(3):169-176. https:// doi.org/10.15381/rpb.v13i3.2334

Pérez ZJ. 2005. Ecologia de Duas Espécies de Lagartos Simpátricos em uma Formação Vegetal de Lomas no Deserto Costeiro Peruano Central. Dissertação de Mestrado. Universidade do Estado do Rio de Janeiro (UERJ). Rio de Janeiro. Brasil.

Pianka ER. 1986. Ecology and Natural history of desert lizards. Princeton University Press. New Jersey, USA, 208 pp.

Pianka ER. 1973. The structure of Lizard Communities. Annual review of ecology and systematics 4:53-74. https:// doi.org/10.1146/annurev.es.04.110173.000413

Ponte M. 1998. Inventario y análisis florístico de la estructura del bosque. En: Wust WH (Ed). La Zona Reservada de Tumbes: Biodiversidad y Diagnóstico Socioeconómico. The John D. and Catherine C. MacArthur Foundation, PROFONANPE, INRENA, Lima, Perú. Pp. 45-65.

Quispitúpac E, Pérez J. 2008. Dieta de la lagartija de las playas Microlophus peruvianus (Reptilia: Tropiduridae) en la playa Santo Domingo, Ica, Perú. Revista Peruana de Biología, 15(2):129-130. https://doi.org/10.15381/ rpb.v15i2.1739

Ribeiro LB. 2010. Ecologia comportamental de Tropidurus hispidus e Tropidurus semitaeniatus (Squamata, Tropiduridae) em Simpatria, em área de Caatinga do Nordeste do Brasil. Tese de Doutorado em Estudos de Comportamento; Psicologia Fisiológica, Universidade Federal do Rio Grande do Norte. Brasil.

Ribeiro LB, Freire EMX. 2011. Trophic ecology and foraging behavior of Tropidurus hispidus and Tropidurus semitaeniatus (Squamata, Tropiduridae) in a caatinga area of northeastern Brazil. Iheringia. Série Zoologia 101(3):225-232. https://doi.org/10.1590/S007347212011000200010

Rocha CFD, Van Sluys M, Vrcibradic D, Kiefer MC, Menezes A, Siqueira C. 2009. Comportamento de termorregulação em lagartos brasileiros. Oecologia Brasiliensis 13(1):115-131. https://revistas.ufrj.br/index.php/ oa/article/view/7067

Rocha CFD, Bergallo HG. 1990. Thermal biology and flight distance of Tropidurus oreadicus (Sauria Iguanidae) in an area of Amazonian Brazil. Ethology Ecology and Evolution 2(3):263-268. https://doi.org/10.1080/08 927014.1990 .9525411

Rouag R, Djilali H, Gueraiche H, Luiselli L. 2007. Resource partitioning patterns between two sympatric lizard species from Algeria. Journal of Arid Environments 69:158168. https://doi.org/10.1016/j.jaridenv.2006.08.008 
Schoener TW. 1975. Presence and absence of habitat shi$\mathrm{ft}$ in some widespread lizard species. Ecological Monographs 45(3):233-258. https://doi. org/10.2307/1942423

Schoener TW. 1974. Resource partitioning in ecological communities. Science 185(4145):27-39. https://doi. org/10.1126/science.185.4145.27

Schoener TW. 1971. Theory of Feeding Strategies. Annual review of Ecology and Systematics 2:369-404. https:// doi.org/10.1146/annurev.es.02.110171.002101

SERNANP. 2012. Plan Maestro Reserva Nacional de Tumbes (2012-2017).

Simpson EH. 1949. Measurement of Diversity. Nature 163(4148):668. https://doi.org/10.1038/163688a0

Smith GR, Ballinger RE. 2001. The ecological consequences of habitat and microhabitat use in lizards: a review. Contemporary Herpetology 3:1-28. https://doi. org/10.17161/ch.vi1.11957

Tello G. 1998. Herpetofauna de la zona reservada de Tumbes. En: Wust WH (Ed). La Zona Reservada de Tumbes: Biodiversidad y Diagnóstico Socioeconómico. The John D. and Catherine C. MacArthur Foundation, PROFONANPE, INRENA, Lima, Perú. Pp. 81-86.

Torres-Carvajal O. 2007. A taxonomic revision of South American Stenocercus (Squamata: Iguania) lizards. Herpetological Monographs 21(1):76-178. https://doi. org/10.1655/06-001.1

Torres-Carvajal 0. 2005. A new species of iguanian lizard (Stenocercus) from the western lowlands of southern Ecuador and northern Peru. Herpetologica 61(1):7885. https://www.jstor.org/stable/3893563

Tracy CR. 1982. Biophysical modeling in reptilian physiology and ecology. In: Gans C, Pough FH (Eds). Biology of the Reptilia, Vol. 12. Academic Press, New York. Pp. 275-321.

Vanhooydonck B, Van Damme R, Aerts P. 2000. Ecomorphological correlates of habitat partitioning in Corsican lacertid lizards. Functional Ecology 14:358-368. https:// doi.org/10.1046/j.1365-2435.2000.00430.x

Vitt, LJ, Pianka ER, Cooper JR WE, Schwenk K. 2003. History and the global ecology of squamate reptiles. The American Naturalist 162(1):44-60. https://doi. org/10.1086/375172

Vitt LJ, Zani PA, Espósito MC. 1999. Historical ecology of Amazonian lizards: implications for community ecology. Oikos 87(2):286-294. https://doi.org/10.2307/3546743

Vitt LJ, Zani PA. 1998. Prey use among sympatric lizard species in lowland rain forest of Nicaragua. Journal of Tropical Ecology 14(4):537-559. https://doi.org/10.1017/ S0266467498000388

Vitt LJ, Carvalho CM. 1995. Niche Partitioning in a Tropical Wet Season: Lizards in the Lavrado Area of Northern Brazil. Copeia 1995(2):305-329. https://doi. org/10.2307/1446894

Watkins GG. 1998. Function of a secondary sexual ornament: the crest in the South American iguanian lizard Microlophus occipitalis (Peters, Tropiduridae). Herpetologica 54(2): 161-169. https://www.jstor.org/stable/3893423

Watkins GG. 1997. Inter-sexual signalling and the functions of female coloration in the tropidurid lizard Microlophus occipitalis. Animal Behaviour 53(4):843-852. https:// doi.org/10.1006/anbe.1996.0350
Watkins GG. 1996. Proximate causes of sexual size dimorphism in the iguanian lizard Microlophus occipitalis. Ecology 77(5):1473-1482. https://doi.org/10.2307/2265544

Winemiller KO, Pianka ER. 1990. Organization in Natural Assemblages of Desert Lizards and Tropical Fishes. Ecological Monographs 60(1):27-55. https://doi. org/10.2307/1943025

\section{Agradecimientos / Acknowledgments:}

AG and JCJA thanks Chief Staff of Cerros de Amotape National Park for allowing use of facilities and research authorization $(R$. J. N 002-2012-SERNANP-DGANP-JE).

\section{Conflicto de intereses / Competing interests:}

The authors declare no conflict of interest.

Rol de los autores / Authors Roles:

AG: Project execution, field work, data analysis and manuscript writing and editing. JCJ: Project administration, data analysis review, manuscript writing and editing.

Fuentes de financiamiento / Funding:

Rufford Small Grants N¹1646-1 granted to JCJ.

\section{Aspectos éticos / legales; Ethics / legals:}

Authors declare that they did not violate or omit ethical or legal norms in this research. Research authorization R. J. $\mathrm{N}^{\circ}$ 002-2012-SERNANP-DGANP-JE. 
Página en banco Blank page 